\title{
Problematika Pembelajaran Sastra Secara Daring di MTsN 11 Tanah Datar
}

\author{
Rafdisyam \\ Rafdisyam93@gmail.com \\ Universitas Negeri Padang, Air Tawar, Indonesia
}

\begin{abstract}
Abstrak. Perubahan sistem pembelajaran konvensional menjadi daring akibat pandemi covid-19 mengalami problematika dalam pelaksanaannya. Pembelajaran sastra yang berada dalam ruang lingkup Mata Pelajaran Bahasa Indonesia menjadi sorotan yang menarik karena sebelumnya dunia sastra telah mengalami perubahan ke arah digital. Meskipun demikian, pelaksanaan pembelajarannya secara daring tidak terlepas dari problematika. Tujuan penelitian ini untuk mengungkap problematika pembelajaran sastra secara daring di MTsN 11 Tanah Datar dari segi guru, siswa, kurikulum, dan sarana. Penelitian dilakukan dengan metode kualitatif. Hasil penelitian tersebut menyimpulkan delapan problematika dalam pembelajaran sastra di MTsN 11 Tanah Datar. (1) guru kesulitan menghadapi siswa yang pasif, (2) guru tidak dapat mengikuti rancangan pembelajaran, (3) guru menghadapi kenyataan bahwa ada siswa yang tidak mengikuti kelas daring sama sekali, (4) guru harus menciptakan metode yang berbeda, (5) guru terbatas dalam mengevaluasi, (6) masih ada siswa yang tidak memiliki gawai, (7) kualitas jaringan yang buruk, (8) kebosanan siswa, (9) belum ada kurikulum khusus pandemi, dan (10) belum adanya sistem $e$ learning yang mumpuni.
\end{abstract}

Kata Kunci: problematika, pembelajaran, sastra, daring

\section{Pendahuluan}

Pada Maret 2020, WHO mengumumkan status pandemi covid-19. Virus yang diduga berasal dari kelelawar tersebut banyak mengubah tatanan kehidupan di berbagai belahan dunia. Salah satu yang terdampak adalah dunia pendidikan. Di Indonesia, kebijakan PSBB (Pembatasan Sosial Berskala Besar) juga memengaruhi sistem pendidikan. Kebijakan pemerintah mengenai sistem pendidikan bagi daerah terdampak covid-19 mulai berlaku pada Maret 2020 dengan bermacam opsi dan pertimbangan. Hal tersebut menjadikan pembelajaran online atau daring menjadi pilihan yang paling mungkin diterapkan.

Pembelajaran daring diartikan sebagai bentuk pembelajaran melalui jaringan komputer yang terkoneksi dengan jaringan komputer lainnya ke seluruh penjuru dunia. Aplikasi pembelajaran daring atau e-learning dapat memfasilitasi aktivitas pelatihan dan pembelajaran serta proses belajar mengajar secara formal maupun informal. Selain itu, e-learning juga memfasilitasi kegiatan dan komunitas pengguna media elektronik, seperti internet, intranet, CDROM, video, DVD, televisi, HP, PDA, dan lain sebagainya (Pratiwi, 2020).

Saat ini, sistem pendidikan berbasis daring masih berlaku meskipun di beberapa daerah telah berganti status dari PSBB ke New Normal. Beragam kritikan dan apresiasi mengenai pembelajaran daring telah banyak bermunculan. Berdasarkan observasi skala kecil dalam tiga daerah di kabupaten yang berbeda yaitu Balai Selasa (Pesisir Selatan), Kampung Baru (Padang), dan Batipuh (Tanah Datar), ditemukan keluhan mengenai sistem pembelajaran daring tersebut. Salah satu keluhan yang muncul mengenai pelaksanaannya yang tidak berjalan efektif. Hal tersebut juga diungkapkan oleh Evayanti (2020). Menurutnya kegiatan tatap muka dengan guru terbukti lebih efektif dibandingkan secara daring (online). Beberapa guru di MTsN Nurul Yaqin Pekanbaru mengaku jika pembelajaran daring ini tidak seefektif kegiatan pembelajaran 
konvensional (tatap muka langsung) karena beberapa materi tidak dapat dijelaskan secara langsung dan tidak lengkap. Pembelajaran daring hanya efektif untuk memberikan penugasan.

Berbeda dengan Evayanti, Mustaqim (2020) menyebut bahwa pembelajaran matematika menggunakan media online cukup efektif. Berdasarkan riset yang dilakukan di SMAN 1 Wejo, Sulawesi Selatan, peserta didik menilai pembelajaran matematika menggunakan media online sangat efektif $(23,3 \%)$, sebagian besar mereka menilai efektif $(46,7 \%)$, dan sisanya memilih biasa saja.

Berdasarkan observasi dan riset tersebut, informasi yang kredibel mengenai pembelajaran daring akan bertambah jika penelitian lanjutan tentang pembelajaran daring pada era pandemi covid-19 dilakukan. Mata pelajaran lainnya yang menarik untuk diteliti pembelajarannya adalah Bahasa Indonesia khususnya bidang sastra. Penelitian mengenai pembelajaran sastra pada era pandemi covid-19 penting untuk diketahui.

Tiga genre sastra, yaitu prosa, puisi dan drama pada perkembangannya juga telah menggunakan media online sebagai mediumnya atau disebut juga dengan sastra digital. Sastra digital pun menjadi alternatif baru bagi sastrawan untuk memperkenalkan karyanya kepada masyarakat (Hidayat, 2008). Sastra digital yang dipublikasikan dari berbagai platform media sosial sangat mudah dinikmati masyarakat atau siswa melalui gawai jika terkoneksi internet. Menurut Wicaksono (2019), media pengajaran sastra mutakhir yang sangat dekat dengan kegandrungan siswa usia sekolah (remaja) adalah media berbasis gawai (gadget). Jadi tidak tertutup kemungkinan bahwa sistem pembelajaran daring akan membuat pembelajaran sastra akan lebih variatif dan memunculkan bermacam problematika.

Terdapat dalam KBBI (Kamus Besar Bahasa Indonesia), problematika berarti hal-hal yang menjadi permasalahan namun belum terpecahkan. Problematika dalam pelaksanaan pembelajaran dapat menjadi acuan bagi guru untuk melakukan evaluasi pribadi untuk menyukseskan pembelajaran selanjutnya. Mengetahui problematika dalam pembelajaran sastra secara daring pada era pandemi covid-19 penting dan sesuai dengan urgensinya. Hasil penelitian mengenai problematika pembelajaran daring juga dapat dijadikan sebagai tolak ukur dan referensi dalam melakukan penelitian lanjutan mengenai hal tersebut.

Penelitian ini bertujuan untuk mengetahui tentang problematika pembelajaran sastra secara daring berdasarkan unsur pembelajaran. Hamalik (2001) mengungkapkan bahwa pembelajaran merupakan suatu kombinasi yang tersusun meliputi unsur-unsur manusiawi, internal material, fasilitas perlengkapan, dan prosedur yang saling mempengaruhi mencapai tujuan pembelajaran. Berdasarkan hal tersebut, sederhananya tujuan penelitian ini untuk mengungkap problematika pembelajaran sastra secara daring berdasarkan unsur manusiawi (guru dan siswa) dan material (kurikulum dan sekolah). Penelitian ini difokuskan pada pembelajaran sastra tingkat menengah karena peserta didik pada tingkat tersebut dianggap sudah bisa menggunakan gawai dengan baik.

\section{Metode}

Penelitian ini menggunakan metode kualitatif deskriptif. Endraswara (2008) menyatakan bahwa penelitian kualitatif dilakukan dengan mengutamakan kedalaman penghayatan terhadap interaksi antar-konsep yang sedang dikaji secara empiris. Menurut Ratna (2008) metode analisis deskriptif digunakan dengan cara menganalisis dan menguraikan data untuk menggambarkan keadaan objek yang diteliti menjadi pusat perhatian penelitian. 
Data dalam penelitian ini berupa hasil wawancara dan observasi mengenai (1) problematika yang dihadapi guru dan siswa dalam pembelajaran sastra secara daring dan (2) problematika yang dihadapi sekolah/kurikulum dalam menunjang pembelajaran sastra secara daring. Penelitian dilakukan di MTsN 11 Tanah Datar. Informan dalam penelitian adalah seluruh Guru Bahasa Indonesia di sekolah tersebut. Wawancara menggunakan alat perekam berupa screen record via whatsapp video call. Hal tersebut dilakukan karena mengikuti anjuran pemerintah untuk melakukan WFH (Work From Home) selama status pandemi diberlakukan.

\section{Hasil dan Pembahasan}

Dalam penelitian mengenai pembelajaran sastra secara daring di MTsN 11 Tanah datar akan dipaparkan hasil dan pembahasan dari wawancara dan observasi tentang (1) problematika yang dihadapi guru dan siswa dalam pembelajaran sastra secara daring dan (2) problematika yang dihadapi sekolah/kurikulum dalam menunjang pembelajaran sastra secara daring.

\section{a. Problematika yang dihadapi guru dan siswa dalam pembelajaran sastra secara daring di} MTsN 11 Tanah Datar

Pertama, dari segi guru. (a) Guru sulit menghadapi siswa yang tidak aktif. Kesulitan tersebut dirasakan oleh guru dalam melakukan pembimbingan dalam menulis teks sastra. Contohnya dalam pembelajaran tentang teks fantasi hanya ada beberapa siswa yang aktif dan bertanya tentang materi tersebut. Teknisnya guru memberikan penugasan dengan cara menonton atau membayangkan sebuah cerita hayalan atau fantasi lalu siswa diminta untuk membuatnya. Keaktifan siswa dalam merespons tugas dinilai minim dalam pembelajaran daring. Ada beberapa faktor sebagai penyebabnya. Hal tersebut dibahas dalam pembahasan permasalahan mengenai siswa.

Selain itu, (b) guru tidak dapat mengikuti sintaks atau rancangan pembelajaran yang seharusnya karena keterbatasan teknis. Guru tidak dapat menggunakan metode pembelajaran saintifik yang seharusnya dilakukan. Guru menciptakan kebijakan dan metode alternatif untuk menyukseskan pembelajaran agar tercapai tujuannya. Salah satu kebijakan yang dilakukan Guru Bahasa Indonesia di MTsN 11 Tanah Datar mencoba menggunakan mind mapping. Namun, dalam mengajarkan siswa untuk menulis terasa sedikit sulit. Sebab, meskipun ada teori langkah-langkah menulis, siswa seharusnya mendapatkan bimbingan secara intensif. Tetapi itu justru terhambat oleh siswa yang pasif sehingga banyak hal yang belum tersampaikan kepada siswa. Cara lain yang dilakukan guru dengan menyajikan video pembelajaran. Berbeda dengan metode mind mapping melalui aplikasi whatsapp sebelumnya, kebijakan yang dilakukan guru dalam mengapresiasi sastra dengan cara pemberian video sastra lebih mudah. Untuk memberikan contoh konten sastra ataupun pembelajarannya, siswa dapat melihat tautan link yang telah dikirim dan dengan mudah dapat diakses melalui kanal youtube. Guru dapat membuat sendiri konten pembelajaran atau mencari konten-konten yang sesuai dengan materi sastra, setelah itu dapat mengirimkannya kepada siswa. Jika siswa terkendala jaringan dan tidak online dalam waktu pembelajara yang telah ditetapkan, siswa masih dapat menonton konten pembelajaran tersebut. Setidaknya permasalahan penyajian materi sastra dalam konteks apresiasi sastra dapat terpecahkan.

Selanjutnya, (c) guru dipusingkan dengan adanya siswa yang tidak ikut kelas daring sama sekali. Permasalahan tersebut membuat guru harus membuat langkah-langkah dalam 
menghadapinya. Jika siswa tidak ada kontak dan tidak bisa dihubungi sama sekali, guru mata pelajaran menghubungi wali kelas yang bersangkutan untuk mendiskusikan cara menyelesaikan persoalan tersebut. Jika siswa terlambat untuk online dan mengikuti kelas di whatsapp grup, masih bisa dimaklumi. Siswa dapat mengakses pembelajaran yang diberikan guru melalui tautan yang disediakan.

(d) Guru harus menciptakan metode yang berbeda kepada tiap siswa yang tidak bisa mengikuti pembelajaran secara umum. Banyaknya permasalahan yang dihadapi siswa membuat mereka tidak bisa mengikuti instruksi pembelajaran yang telah dirancang guru. Ada siswa yang hanya bisa mengikuti pembelajaran melalui whatsappgrup saja, ada yang bisa melalui kanal youtube saja, bahkan ada yang tidak bisa ikut pembelajaran daring. Jadi guru menciptakan berbagai cara untuk menyiasati permasalahan tersebut. Misalnya siswa yang tidak bisa daring namun memiliki keinginan tinggi untuk belajar, mereka akan datang ke sekolah. Guru dapat menemuinya dengan tetap mengikuti protokol kesehatan covid-19.

(e) Dalam melakukan evaluasi, keberhasilan siswa yang paling umum dalam pembelajaran hanya dapat terlihat melalui keaktifan. Siswa yang aktif terlihat lebih berusaha untuk bertanya atau mencari informasi tersendiri mengenai pembelajaran. Ada siswa yang bertanya tentang pelajaran secara pribadi, bahkan setelah selesai pembelajaran melaui grup whatsapp. Hal tersebut menjadi indikator tersendiri dalam membuat kebijakan dalam pembelajaran. Dalam melakukan penilaian guru dituntut untuk tetap memberikan nilai walaupun ada siswa yang tidak memiliki kehadiran atau kabar sama sekali. Hal tersebut menjadi persoalan tersendiri dalam melakukan evaluasi pembelajaran. Dalam kasus tersebut guru juga tidak bisa memaksa siswa untuk mengikuti pembelajaran daring, yang terpenting itikad dan niat siswa dalam mengikuti pembelajaran menjadi penilaian tersendiri.

Kedua, problematika dari segi siswa. (a) Masih ada siswa yang tidak memiliki perangkat telepon (gawai). Hal ini terjadi karena siswa di sekolah tersebut sebagian besar terbilang kurang mampu. Ada yang menggunakan gawai orang lain untuk mengakses pembelajaran daring.

(b) Jaringan internet yang tidak selalu baik. Kualitas sinyal/jaringan internet berpengaruh besar dalam pembelajaran daring. Topografi daerah Tanah Datar yang merupakan dataran dan perbukitan memiliki pengaruh terhadap jaringan karena tempat tinggal siswa tidak terintegrasi pada pusat kota saja.

(c) Siswa merasa bosan dengan pembelajaran sastra yang tidak variatif. Metode yang dilakukan guru pada pembelajaran sastra hanya menulis teks saja. Pembelajaran yang hanya difokuskan kepada menuis teks tentu akan membosankan walaupun sebelumnya diberikan penugasan berupa materi tentang teks tersebut. Pemberian materi secara daring dirasa tidak efektif. Oleh karena itu pembelajaran difokuskan pada ranah menulis teks. Teknisnya siswa menulis teks, lalu memfoto gambar teks yang telah ditulis dan dikirim ke guru.

Sejalan dengan permasalahan tersebut, Hapsari dan Fitria (2020: 18) mengungkapkan bahwa kesiapan penggunaan teknologi dan internet dirasa masih kurang untuk memenuhi tagihan pertemuan kuliah dalam pembelajaran, untuk itu diperlukan adanya peningkatan jaringan dan fasilitas pendukung yang memadai. Hal tersebut memperkuat pernyataan sebelumnya tentang permasalahan yang dihadapi dalam pembelajaran daring walaupun di 
tingkat Perguruan Tinggi. Jadi dalam pembimbingan siswa secara intensif masih menemukan kendala teknis.

\section{b. Problematika yang dihadapi sekolah/kurikulum dalam menunjang pembelajaran sastra secara daring di MTsN 11 tanah Datar}

Problematika dari segi kurikulum yaitu belum ada kurikulum khusus yang dirancang untuk situasi pandemi. Kurikulum masih menggunakan kurikulum lama dengan beberapa penyesuaian. Hal tersebut dapat dimaklumi karena pandemi datang secara tiba-tiba dan termasuk ke dalam keadaan darurat nasional. Jadi pemerintah hanya memindahkan kelas yang biasanya di sekolah ke rumah masing-masing melalui pembelajaran daring dengan beberapa pertimbangan.

Pada masa pandemi, pelaksanaan pembelajaran berfokus pada butir silabus yang memuat materi esensial saja. Artinya, tidak semuanya yang diajarkan kepada siswa untuk pembelajaran sastra hanya terfokus kepada pemahaman tentang hakikat teks sastra itu sendiri dengan langkah-langkah menulisnya. Harapanya, jika mereka bisa menulis, berarti mereka mampu memahami materi secara tidak langsung.

Kedua, dari segi sekolah/sarana pembelajaran pada masa pandemi. Sarana yang diberikan pemerintah Indonesia berupa kuota untuk belajar kepada siswa dan guru. Dari segi sekolah sendiri belum memiliki sarana berupa e-learning. Hal tersebut sangat terbatas karena untuk memiliki sistem e-learning tidak mudah dan membutuhkan proses yang panjang.

Selain hal tersebut, permasalahan sarana juga terjadi pada siswa karena masih ada siswa yang belum memiliki gawai. Di MTsN 11 Tanah Datar belum ada kebijakan khusus untuk memfasilitasi siswa melalui pemberian gawai untuk yang tidak memilikinya. Permasalahan tersebut bisa tumpang tindih antara kebijakan pemerintah sendiri. Siswa yang tidak memiliki gawai dapat menggunakan penyewaan warung internet (warnet) namun pada masa pandemi hal tersebut juga tidak memungkinkan. Kebijakan yang dilakukan MTsN 11 Tanah Datar untuk mengatasi masalah tersebut ialah memberikan kuota eksis gratis kepada siswa. Namun, tidak semua siswa mau mengambilnya karena provider tersebut belum memiliki sinyal yang mumpuni di daerah tempat tinggal mereka. Seharusnya pemilihan provider juga menjadi bahan pertimbangan bagi sekolah dalam memfasilitasi siswa.

\section{Simpulan}

Pembelajaran daring dalam mata pelajaran Bahasa Indonesia pada bidang sastra di MTsN 11 Tanah Datar mengalami berbagai problematika. Pertama, permasalahan dari segi guru dan siswa. Problematika tersebut berupa (1) kesulitan guru dalam menghadapi siswa yang pasif, (2) guru tidak dapat mengikuti sintaks atau rancangan pembelajaran yang seharusnya karena keterbatasan teknis, (3) guru dipusingkan dengan adanya siswa yang tidak ikut kelas sama sekali, (4) guru harus menciptakan metode yang berbeda kepada tiap siswa yang tidak bisa mengikuti pembelajaran secara umum, (5) dalam melakukan evaluasi, keberhasilan siswa yang paling umum dalam pembelajaran tersebut hanya dapat terlihat melalui keaktifan, (6) masih ada siswa yang tidak memiliki perangkat telepon (gawai), (7) jaringan yang tidak selalu baik dan (8) siswa merasa bosan dengan pembelajaran sastra yang tidak variatif. 
Kedua, permasalahan pembelajaran sastra secara daring di MTsN 11 Tanah Datar secara daring dari segi sekolah/kurikulum. Permasalahan tersebut ialah belum ada kurikulum khusus yang dirancang untuk situasi pandemi dan belum adanya sistem e-learning yang mumpuni.

Berdasarkan kesimpulan dari penelitian tersebut, terdapat saran. (1) Untuk guru agar melakuan inovasi dan membuat analisis kebutuhan sebagai acuan untuk pembelajaran selanjutnya. (2) Siswa hendaknya berusaha lebih aktif dalam mencari materi dan membantu siswa lain yang mengalami kesulitan akses jika tidak semua permasalahan teknis terselesaikan oleh guru dan sekolah. (3) Pemerintah sebagai otoritas pembuat kebijakan dan fasilitator terus mengupayakan perbaikan jaringan interntet. (4) Untuk peneliti selanjutnya agar dapat melakukan penelitian kuantitatif untuk mengukur keefektifan pembelajaran sastra secara daring pada skop yang lebih luas.

\section{Daftar Pustaka}

Endraswara, Suwardi. 2008. Metodelogi Penelitian Sastra. Yogyakarta: Media Pressindo.

Evayanti, Desi. 2020. Efektivitas Pembelajaran Melalui Metode Daring (Online) Dalam Masa Darurat Covid-19: STIT Al-Khifayah Riau Sumber Negeri Serumpun. [Online]. Available https://www.stit-alkifayahriau.ac.id

Hapsari dan Fitria. 2020. Efektivitas Pembelajaran Daring Mata Kuliah Evaluasi Pengajaran Bahasadan Sastraindonesia Masa Pandemi Covid-19: Jurnal Ilmiah SEMANTIKA Volume 2, No. $\quad$ 01, $\quad$ Agustus $\quad 2020, \quad$ p. $11-20$ (online)availablehttp://jurnal.umus.ac.id/index.php/semantika/article/view/259/semantika Hidayat, Arif. 2008. Sastra Cyber: Alternatif Komunikasi antara Karya Sastra dan Masyarakat Pembaca: Komunika. Volume 2 No 2 tahun 2008.

Mustaqim. 2020. Efektivitas Pembelajaran Daring Menggunakan Media Online Selama Pandemi Covid-19 Pada Mata Pelajaran Matematika: Al asma: Journal of Islamic Education ISSN 2715-2812 (Online) Vol. 2, No. 1, May 2020

Oemar, Hamalik. 2001. Kurikulum dan Pembelajaran. Jakarta: PT. Bumi Aksara

Pratiwi, Ericha Windhiyana. (2020). Dampak Covid-19 terhadap Kegiatan Pembelajaran Online di Sebuah Perguruan Tinggi Kristen di Indonesia: Jurnal Perspektif Ilmu PendidikanVol.34 No. 1 April tahun 2020 hlm. 1-8. [Online]. Available: http://doi.org/10.21009/PIP.341.1

Pusat Bahasa Depdiknas. 2005. Kamus Besar Bahasa Indonesia. Jakarta: Balai Pustaka

Ratna, Nyoman Kutha. 2009. Stilistika, Kajian Puitika Bahasa, Sastra, dan Budaya. Yogyakarta: Pustaka Pelajar

Wicaksono. 2019. Revolusi Pengajaran Sastra Indonesia 4.0: Prosiding Seminar Nasional 2019 "Bahasa, Sastra, dan Pembelajarannya di Era Digital" 